\title{
GROWTH STRATEGIES OF ELECTRIC UTILITIES IN CONTEXT OF DEREGULATION AND LIBERALIZATION OF ELECTRICITY MARKET
}

\author{
Maria Đogic**
}

Received: 3. 7.2017

Review

Accepted: 27. 10. 2017

UDC 005.21:611.31(497)

\begin{abstract}
This paper identifies the growth strategies adopted by the electric utilities sector in the context of changes resulting from the deregulation and liberalization of the electricity market. Strategies pursued by the electric utilities sector were rarely the subject of research in the field of strategic management despite the fact that electricity is an indispensable element of everyday life and the economy as a whole. Therefore, a case study of the largest incumbent electric utilities in the Republic of Croatia, Slovenia, Bosnia and Herzegovina, Serbia, Montenegro, and Macedonia has been conducted, and differences in the degree of market liberalization and core features of these companies have been noted. Research
\end{abstract}

\section{INTRODUCTION}

Liberalization and deregulation of the electricity market are a part of a wider trend towards the withdrawal of state influence from the infrastructure industry (Schneider \& Jäger, 2003). The main goal of liberalization in the electricity market is to enable competition through restructuring of the entire power sector which was often based on ownership transformation of incumbent electric utilities that generated, transmitted, findings have shown that the degree of deregulation can affect the growth strategies of electric utilities. In those countries where the degree of deregulation is lower, electric utilities focus on the domestic market. On the other hand, a higher level of deregulation enables electric utilities to achieve their growth through diversification or innovation. Given the fact that the analyzed electric utilities are operating within relatively small economies, they cannot compete with electric utilities in developed countries, and, apart from international electricity trading, are mostly focused on their domestic markets.

Keywords: growth strategies, electric utilities, deregulation, electricity market liberalization, internationalization

distributed and supplied electricity (Ernst \& Young, 2006) Incumbent electric utilities are the electric utilities that were present before the official liberalization of the electricity market as a state-owned monopoly. These companies had sole ownership of all the production facilities, as well as the entire transmission and distribution network. Private investors were unable to enter the market and consumers were unable to choose their own electricity. Power industry was fully regu-

* Maria Đogić, M.Econ., PhD candidate, Expert associate in JP Elektroprivreda HZ HB d.d. Mostar, Ulica Mile Budaka 104a, 88000 Mostar, Bosnia and Herzegovina, e-mail:maria.dogic@ephzhb.ba 
lated, and electricity prices were determined by calculating the required revenue needed to cover the costs of production and transmission/distribution as well as the administrative costs of the company. Through the implementation of the public tariff procedure, regulatory agencies directly influenced the electricity prices. This was manifested in the existence of cross-subsidies between the consumer categories. Cross-subsidization served as a tool for implementing a specific kind of social policy, i.e. considerably lower electricity prices for households were subsidized by the higher prices of electricity for the commercial consumers. The need for deregulation in the case of public utility companies in the power sector emerges from the idea that public companies do not have proper incentives to optimize and reduce their costs, and are subject to political pressures of governments and political parties and, therefore, they do not operate at an optimal level (Mejía-Dugand, Hjelm, \& Baas, 2017).

Despite the formal liberalization of the electricity market, changes in the power sector in many European countries have been rather slow and modest (Ratinen \& Lund, 2014). Competition in the power industry is still scarce, primarily because barriers for new competitors remain high. Incumbent electric power companies still retain the largest share in the infrastructure in the process of electricity generation and are therefore perceived as key drivers of future changes in this industry (Humphreys \& Padgett, 2006).

Previous research on strategic behavior of electric utilities focused on examining the specifics of the electric utilities' strategies or testing the established theoretical models in specific environments. Only a few studies (Russo, 1992; Mahon \& Murray, 1981; Vietor, 1994; Ghobardian, et al., 1998) analyzed current business and strategic management of former monopolies or companies whose business was largely regulated, in new environments and in the context of liberalized electricity markets. Bonardi (2004) emphasizes that the strategies of now deregulated former monopolies must be a subject of interest of comprehensive research and not just a specific area for testing the theory of strategies or competitive advantages in changing environments. This paper analyzes the growth strategies adopted by the electric utilities using a proposed system approach (Whittington, 1993) and a typology presented by Ratinen and Lund (2014) in order to compare the growth strategies of electric utilities in the selected countries. Such approach takes into account the slow technological changes inherent to the electricity infrastructure that was a product of specific historical, socio-economic, resource and other conditions. (Ratinen \& Lund, 2014)

\section{THEORY REVIEW}

\subsection{Liberalization and deregulation of the electricity market}

Electricity industry is characterized by a number of specifics that shaped its optimal regulatory framework (Jamasb \& Pollit, 2005), including:

- Large non-refundable costs that limited the entry into the market

- Vertical integration of electric utilities (production-transfer-distribution-supply)

- The fact that electricity cannot be stored and is transferred through network that requires the immediate physical balance of supply and demand.

The process of delivering electricity to final consumers is comprised of four separate but interconnected processes: electric- 
ity generation, transmission of electricity (through high voltage network), distribution of electricity (through medium and low voltage network) and electricity supply to customers. These four processes have different economic characteristics. Production and supply (including measurement and collection) are potentially competitive because current technology allows multiple companies to operate in the market, thus disabling monopolistic benefits, while transmission and distribution are natural monopolies at a national/regional level. Access to the network, through either transmission or distribution, should therefore be regulated in order to ensure equality and non-discrimination of all market participants (Ferrari \& Giulietti, 2005).

The liberalization of the electricity market generally requires the implementation of one or more steps (Jamasb, 2002, MüllerJentsch, 2001.):

1. Restructuring and corporatization of state-owned enterprises - Electricity market reforms imply separating vertically integrated incumbent electric utilities and conducting activities to lessen the horizontal concentration.

2. Separation of regulatory and operational activities and creating a coherent regulatory framework by establishing an independent regulatory agency in order to protect the interests of consumers /customers and to promote competition

3. Vertical separation of production, transmission, distribution and supply processes - The aim of the separation of vertically integrated electric utilities is to separate electricity production and supply from electricity transmission and distribution, define the rules of access to the network and ensure a nondiscriminatory treatment for third parties (Ferrari \& Giulietti, 2005).
4. Introduction of competition in the area of electricity production and electricity supply and implementing regulation on transmission and distribution of electricity

5. Promotion of private investments and private management through privatization, concession and market entry

6. Reduction of subsidization and tariff rebalancing in order to equalize prices and costs and to reduce and limit irregularities present in the electricity market

One of the main goals of liberalization is to increase the market size (either in the form of larger regional and interregional markets or through formation of a large single market), as well as to establish a perfect competition in the market where the most efficient producers have the largest market share (Jacobsen, Fristrup, \& Munksgaard, 2006; Olley \& Pakes, 1996; Seabright, 2001). Through a carefully thought out and properly designed liberalization process it should be possible to achieve significant savings for the power system as a whole (Newbery, Strbac, Pudjianto, \& Noël, 2013). However, given the significant differences in the organization of the individual electricity markets as well as different ownership models of the electric utilities in the European Union Member States, it became necessary to harmonize the basic rules and establish the minimum requirements for a liberalized electricity market, with respect to specificities of individual states (Tominov, 2008) through the implementation of EU Directives. An overview of the basic requirements defined by individual EU Directives relating to the liberalization of the electricity market is given in Table 1.

The process of adapting to the new conditions for the transition countries has been and still remains far more difficult, primarily because the electric utilities in these coun- 
Table 1: Basic requirements stated in the EU Directives

\begin{tabular}{|c|c|c|}
\hline \multicolumn{2}{|c|}{ EU Directive } & \multirow{2}{*}{\begin{tabular}{l}
\multicolumn{1}{c|}{ Basic requirements } \\
Establishing a competitive electricity market \\
Developing interconnections \\
Obligation to supply customers who have not chosen a new supplier for themselves \\
Separating the transmission operator \\
Enabling wholesale competition
\end{tabular}} \\
\hline First EU Directive & $6 / 92 / \mathrm{EC}$ & \\
\hline Second EU Directive & 2003/54/EC & $\begin{array}{l}\text { Establishing a "last haven" supplier } \\
\text { Customer protection programmes } \\
\text { Regulated and non-discriminatory access to the network } \\
\text { Enabling competition in the electricity production process }\end{array}$ \\
\hline Third EU Directive & 2009/72/EC & $\begin{array}{l}\text { Including individual country's regulators into a common regulatory agency - (ACER) } \\
\text { Enhancing the regulation of transmission and distribution of electricity on a national level } \\
\text { Increasing cooperation between transmission system operators (TSOs) } \\
\text { Obligation of separating TSOs from production and supply } \\
\text { Separation of distribution system operators from production and supply } \\
\text { Redefined customer protection programs }\end{array}$ \\
\hline \multirow{3}{*}{$\begin{array}{l}\text { Other Directives in } \\
\text { the field of } \\
\text { electricity market } \\
\text { regulation }\end{array}$} & 2001/77/EC6 & $\begin{array}{l}\text { Promotion of electricity production from renewable energy sources in order to ensure and } \\
\text { diversify the electricity supply, economic and social cohesion and environment protection }\end{array}$ \\
\hline & $1228 / 2003 / \mathrm{EC} 8$ & $\begin{array}{l}\text { Regulation of electricity transmission between Member States and establishing compensation } \\
\text { mechanisms for an inter-transmission system operator, defining rules for the availability of } \\
\text { international capacity usage }\end{array}$ \\
\hline & 2005/85/EC10 & $\begin{array}{l}\text { Maintaining the security of electricity supply and ensuring the proper functioning of the } \\
\text { internal electricity markets in terms of interconnections between Member States as well as } \\
\text { sufficient production levels and supply and demand balancing }\end{array}$ \\
\hline
\end{tabular}

Source: Research results (according to Tominov, 2008)

tries faced these changes with a significant negative legacy. It is important to note that electricity was treated as a commodity that had to be available to all consumers in sufficient quantities regardless of the price. Such attitude toward electricity led to unrealistic and low electricity prices for the household consumers that subsequently made it difficult for electric utilities to make any strategic investment decisions. The development of the power industry was achieved through various types of state interventions such as budget subsidies, state-funded capital investments, state guarantees for loans etc. In the years prior to liberalization there appeared to be no significant developments in the electricity industry whatsoever (Granić, Zeljko, Moranjkić, Andres Martinez, Olano, \& Jurić, 2008). On the other hand, incumbent electric utilities wanted to retain their market share after liberalization and exploit their positions of formerly vertically inte- grated state-owned monopolies as well as their connections to government and regulators in order to influence market entry and secure their positions (Ringel, 2003). Expected benefits from electricity market liberalization in transition economies included increased investments in the industry due to ever-increasing electricity demand and their significant energy potential. However, the sector has seen an almost negligible volume of foreign investment since the opening of the market (Družić, Štritof, \& Gelo, 2012). The most prominent obstacles to the efficient and fast liberalization of the electricity market in transition economies are potential social problems that could arise from the reduction in the number of employees in the electricity sector as well as from adjusting the electricity prices for households to the electricity market price. There also seems to be a significant rush to implement the electricity market reforms in transition econo- 
mies, commonly by copying some kind of preexisting models (at least at the legislative level) used in developed economies without considering specificities of power sectors in individual countries (Tominov, 2008).

\subsection{Growth strategies of electric utilities}

Previous research in the field of strategic management argues that a certain company or organization must adopt coherent and distinctive strategies (Andrews, Boyne, Law, \& Walker, 2009) and adapt their internal features to those strategies. The electric power industry has all the features of a natural monopoly - before the electricity market reforms competition was prevented from entering the market, especially in the process of electricity generation (Nakano \& Managi, 2008), so electric utilities as natural monopolists did not have to think about their strategies in the context of competition. Despite the liberalization of the electricity market, incumbent electric utilities have not significantly altered their strategies. Clifton et al. (2010) found that there is no universal logic in how incumbent electric utilities respond to changes in the electricity market and the strategies of electric utilities adopted in face of changed business environment depend on various factors. For example, electricity companies that have no renewable energy sources in their production domain are unlikely to integrate these technologies into their plans as opposed to power utility companies with previous experience in these technologies (Stenzel \& Frenzel, 2008). Since the incumbent electric utilities were regulated monopolies for a long time, they may have limited possibilities and experience necessary to identify new markets and new market opportunities. On the other hand, even though the liberalization process leads to immanent disintegration of natural monopolies, it has not yet contributed to re- ducing the concentration within the sector itself. There are still national and regional markets in which the incumbent electric utilities are quite predominant (Domanico, 2007) and can significantly influence the dynamics of electricity market reforms (Ratinen \& Lund, 2014).

According to the systemic approach chosen for the purpose of this analysis, growth strategies adopted by the electric utilities are based on innovation, internationalization or diversification of activities (Whittington, 1993). The basic features of the innovationbased growth strategy relates to the creation of new business opportunities (Ratinen \& Lund, 2014), for example provision of energy efficiency consulting services, project development services for the construction of new electric power facilities and so on. This study defines innovation as investments in production facilities that use new technologies or investments in improving the efficiency of already existing facilities. What distinguishes the innovation strategy from the diversification strategy is the fact that the core business of the incumbent electric utility remains the same but is improved through innovation. Electric utilities adopting the diversification-based growth strategy diversify their activities and apart from production, distribution and supply of electricity venture into other businesses such as the developing and producing components for the construction of new production facilities, setting up and producing charging points for electric cars, venturing into telecommunication services, etc. Internationalization, as a growth strategy relates to the expansion of incumbent electric utilities of one country to the territories of other countries.

Ratinen and Lund (2014) base their assessment of incumbent electric utilities' adopted growth strategies in Denmark, Germany, Finland and Spain on two criteria: 
- Focus on the market - the strategies of internationalization of operations, i.e. the degree of internationalization of the company's operations in relation to other observed companies determine the market orientation criterion whereas internationalization implies the geographical location of certain segments of the company's business outside of its domestic market. enterprises, governments (after every elections or change of government) nominate and confirm top management in electric utilities and subsequently influence their strategies. As such, the connection with the government (state or local) is imminent to the incumbent electric utilities, and its intensity is difficult to determine. On the other hand, the degree of deregulation of the electricity market can be determined

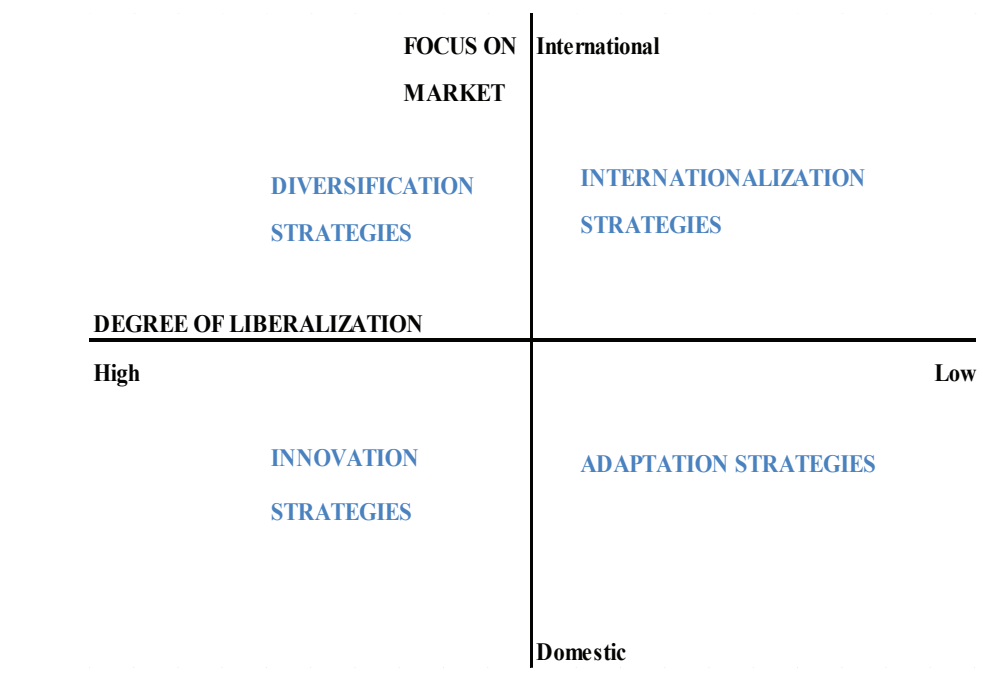

Source: Research results (based on Ratinen\& Lund, 2014, p. 82)

Figure 1: Growth strategies for electric utilities in the context of electricity market liberalization

- The relative strength of social relations - this criterion is based on determining the strength of links between the incumbent electric utilities and their governments or regulatory agencies. In this paper, a modification of this criterion is proposed, and instead of evaluating the links between incumbent electric utilities and their governments/ regulators, this analysis takes into consideration the degree of market deregulation in a given country. Since the majority of electricity companies in the observed area are state owned by assessing compliance to relevant EU regulations concerning the deregulation of the electricity market. This approach is illustrated by Figure 1 where the degree of internationalization of business is the axis $y$, and the level of compliance with EU directives is the axis $\mathrm{x}$.

Based on these dimensions, four categories of potential growth strategies for incumbent electric utilities (based on their main characteristics) are defined: Internationalization Strategy, Diversification 
Strategy, Adaptation Strategy and Innovation Strategy. Incumbent electric utilities operating in countries that have only partially aligned their legislation with the requirements of the EU Directives, and their business or certain segments of their businesses is internationalized, i.e. they seek growth through mergers and acquisitions on international markets, are adopting the strategy of internationalization. Electric utilities from developing and transition economies cannot compete with the electric utilities in the developed European Union economies, so adopting the strategy of globalization or internationalization of business at this point seems very unlikely (Li, Sun, \& Liu, 2006). The governments in transition countries seek to protect their incumbent electric utilities, but at the same time, expect to achieve certain benefits for electricity consumers through the liberalization of the electricity market.

Contrary to the above, the research on the strategic behavior of former monopolies from developed countries indicates that optimal strategies for former electric utility monopolies are the strategies of globalization and internationalization (Bonardi 2004). Namely, since the headquarters of multinational companies are mostly located in developed economies, the fact that their business is already present in an international market enables the incumbent electric utilities from developed countries to penetrate the new markets. However, even though incumbent electric utilities adopt the internationalization (global) strategies and are expanding their businesses on foreign markets they are simultaneously trying to affect deregulation in their states and maintain their position by preventing the competition from entering the electricity market. Electric utilities, as former monopolies following the years of regulation and already established contacts with authorities use their experience and connections to their advantage in their do- mestic markets. This indicates the asymmetric behavior of former monopolies in their political and economic strategies (Bonardi, 2004). Asymmetric behavior in this context refers to a behavior that integrates international expansion on the economic side with defensive activities on the political side, i.e. incumbent electric utilities are taking the advantage of a "stable domestic base" to take over the electric utilities of neighboring countries while maintaining their position in their own market (Bonardi, 2004).

If the electric utility operates in a country with a fully liberalized electricity market and does not adopt an internationalization strategy but focuses on their domestic market, it will adopt a growth strategy based on innovation. As such, the electric utility seeks to improve its own market position by focusing on the domestic market, while adapting to the new market conditions at the same time.

Companies that base their growth strategies on diversification cannot influence the content of liberalization policies and their implementation. They are operating in liberalized markets and facing numerous competitors. In order to achieve growth, these electric utilities focus on finding new technologies and new markets or segments of particular markets.

The adaptation strategy is adopted by the incumbent electric utilities operating in countries that have not yet fully liberalized their electricity markets. Incumbent electric utilities cannot influence the implementation or outcome of liberalization policies and have no choice but to adapt their strategies and respond to changes relating to the process of deregulation of the electricity market. 


\section{METHODOLOGY AND DATA}

This article analyzes how the degree of deregulation affects the strategies of incumbent electric utilities. The research is conducted by studying specific cases of incumbent electric utilities in selected South Eastern European countries. Qualitative research and case study method has been used since the aim of this paper is to analyze the individual growth strategies of each company in relation to the degree of liberalization for each country, as well as to compare their growth strategies. Research material used in this analysis consists of primary and secondary sources. The primary sources used are the incumbent electric utility's annual and semiannual reports which they are obligated to publicize, publicly disclosed ownership data, available data on planned future investments, data on electricity production, organizational structure and other available data.

The evaluation of the degree of deregulation of electricity markets and the compliance with the EU Directives is based on the secondary data collected from publications and available databases, publications of regulatory bodies and ministries in charge of the power sector. The analysis of market orientation of electric utilities was based on the data regarding the markets at which the companies operate and activities in which they operate in the given markets (Ratinen \& Lund, 2014). For example - investigating whether the company participates actively in domestic or foreign electricity exchanges and whether there are clear plans for their expansion to foreign markets should determine the degree of internationalization for a specific country.

For the purpose of analyzing the diversification within the power company, the organizational structure of the enterprise itself was examined. Diversification of activities was noted when electric utility engaged in business activities that were not directly related to generation, distribution and supply of electricity. It is important to note that investments in production facilities that use electricity for the production of electricity using renewable energy sources are not considered diversification of business but rather an innovation, because although the technology used is new and different, the essence of business remains the same electricity generation.

The collected data is analyzed and compared and all material used has been listed in the references. However, since data collecting required many different sources, and considering the fact that web based sources are continuously changing, only main websites used to find relevant information were listed.

\section{RESEARCH RESULTS}

The countries of South Eastern Europe, i.e. transition countries of former Yugoslavia, are chosen for this research, primarily because the electricity industry in these countries matured and operated in equal historical and economic conditions thus enabling comparisons of the degree of liberalization progress between the selected countries. An overview of the electric utilities operating in the selected countries is given in Table 2.

As these countries are signatories to the Energy Convention, they are facing similar requirements made by the Energy Community with which they strive to comply by adapting to the required changes in their own way and at their own pace. An incumbent electric utility (or several of them), from every country was selected for the purpose of this research provided they are active in the process of electricity production. 
Table 2: Basic information of selected electric power utilities

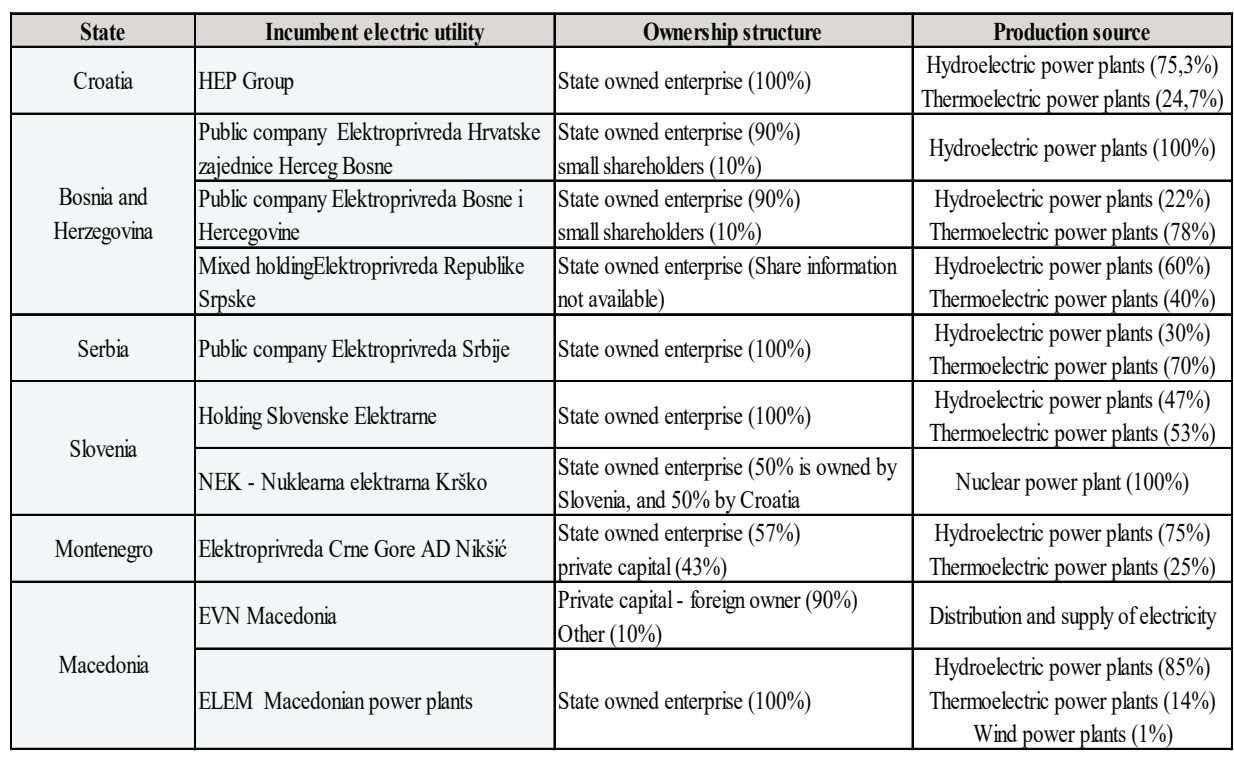

Source: Research results

Certain electric utilities perform other activities such as electricity supply or distribution along with electricity production, while electricity transmission is functioning as an independent company in most countries. Of the above-mentioned electric utilities, NEK (Krško Nuclear Power Plant) was excluded from the analysis because it is a single production plant with joint Croatian and Slovenian ownership, as well as EVN Macedonia, since it does not include the process of electricity production and it has been privatized. However, even though EVN Macedonia was not the subject of this research, the private ownership was taken into account and contributed to evaluating the degree of deregulation (liberalization) in Macedonia, since privatization of electric utilities is an indicator of highly liberalized electricity markets.

As it is apparent from Table 2, selected electric utilities are state-owned enterprises, and the electricity generation structure consists of hydroelectric power plants and thermoelectric power plants, where the share of each in the total generation of electricity varies from $22 \%$ in $\mathrm{EP} \mathrm{BiH}$ up to $100 \%$ in $\mathrm{EP}$ HZ HB. The above illustrates the differences between the electric utilities in the context of the resources used and available for electricity generation.

\subsection{The degree of liberalization of the electricity market}

In order to evaluate the degree of liberalization of the electricity market in each country, indicators of compliance with EU Directives for individual countries as well as for specific electric utilities have been identified and put into context.

Electric utilities are required to carry out a certain form of restructuring and/or reorganization of business processes and activities but it is left to them (providing they respect certain rules and guidelines) to choose in which way they will accomplish this task. For example, electric utilities operating within Bosnia and Herzegovina are facing the same legal regulations and 
regulatory frameworks, but they reorganized in different ways and are therefore separately presented in the restructuring segment of this analysis. The degree of liberalization was evaluated based on the parameters relating to "best practice" cases that coincide with requirements stated in the European Union Directive (Müller-Jentsch, 2001). An overview of the requirements related to liberalization and deregulation of the electricity market is given in Table 3 . distribution processes and the allowing competition in the electricity generation process. Although all of the observed countries have formally opened their wholesale and retail electricity markets, thus enabling entrance to third parties, Croatia (2008) and Slovenia (2007) have opened their markets significantly earlier than other countries (2015). Every country also stimulates the electricity generation from renewable sources, but the share of renewable

Table 3: Evaluation parameters of the degree of liberalization of electricity markets in selected countries

\begin{tabular}{|c|c|c|c|c|c|c|c|c|}
\hline State & Croatia & \multicolumn{3}{|c|}{ Bosnia and Herzegovina } & \multirow{2}{*}{$\begin{array}{c}\text { Serbia } \\
\text { EPS }\end{array}$} & \multirow{2}{*}{$\begin{array}{c}\text { Slovenia } \\
\text { HSE }\end{array}$} & \multirow{2}{*}{$\begin{array}{c}\text { Montenegro } \\
\text { EP CG }\end{array}$} & \multirow{2}{*}{\begin{tabular}{|c} 
Macedonia \\
ELEM
\end{tabular}} \\
\hline Electric utility & HEP Group & ЕР HZ HB & ЕР ВiH & MH ERS & & & & \\
\hline $\begin{array}{l}\text { Enterprise restructuring and corporatization of } \\
\text { state-owned enterprises }\end{array}$ & Yes & No & Yes & Yes & Yes & Yes & No & Yes \\
\hline $\begin{array}{l}\text { Separation of regulated and operational } \\
\text { activities / vertical separation }\end{array}$ & Yes & No & No & Yes & Yes & Yes & Yes & Yes \\
\hline \multirow{2}{*}{ Setting up an independent regulator } & \multirow{2}{*}{ HERA } & \multicolumn{3}{|c|}{ DERK } & \multirow{2}{*}{ AERS } & \multirow{2}{*}{ AGEN-RS } & \multirow{2}{*}{ REGAGEN } & \multirow{2}{*}{ ERC } \\
\hline & & FEF & & RERS & & & & \\
\hline $\begin{array}{l}\text { Transmission and distribution of electricity - } \\
\text { regulated activities }\end{array}$ & Yes & \multicolumn{3}{|c|}{ Yes } & Yes & Yes & Yes & Yes \\
\hline Opening up the wholesale and retail market & Yes & \multicolumn{3}{|c|}{ Yes } & Yes & Yes & Yes & Yes \\
\hline $\begin{array}{l}\text { Date of official opening of the electricity } \\
\text { market }\end{array}$ & 2008. & \multicolumn{3}{|c|}{2015.} & 2015 . & 2007. & 2015. & 2015. \\
\hline Privatization of electric utilities & No & \multicolumn{3}{|c|}{ No } & No & No & Partly & Yes \\
\hline $\begin{array}{l}\text { The existence of cross-subsidization in the } \\
\text { segment of supply of end-customers }\end{array}$ & No & \multicolumn{3}{|c|}{ Yes } & Yes & No & Yes & Yes \\
\hline $\begin{array}{l}\text { Existence of the National Electricity } \\
\text { Exchange }\end{array}$ & Yes & \multicolumn{3}{|c|}{ No } & Yes & Yes & Yes & No \\
\hline $\begin{array}{l}\text { The introduction of competition in the } \\
\text { production segment }\end{array}$ & Yes & \multicolumn{3}{|c|}{ Yes } & Yes & Yes & Yes & Yes \\
\hline $\begin{array}{l}\text { The share of the largest producer in total } \\
\text { electricity generation }\end{array}$ & $\begin{array}{l}78 \% \\
(-5 \%)\end{array}$ & \multicolumn{3}{|c|}{$\begin{array}{c}48 \% \\
(+2 \%)\end{array}$} & $\begin{array}{l}99 \% \\
(0 \%)\end{array}$ & $\begin{array}{l}51 \% \\
(-1 \%)\end{array}$ & $\begin{array}{l}98,5 \% \\
(-1 \%)\end{array}$ & $\begin{array}{l}90,2 \% \\
(-2,5 \%)\end{array}$ \\
\hline $\begin{array}{l}\text { A system for promoting the integration of } \\
\text { renewable energy sources }\end{array}$ & Yes & \multicolumn{3}{|c|}{ Yes } & Yes & Yes & Yes & Yes \\
\hline $\begin{array}{l}\text { Share of renewable energy sources in total } \\
\text { production }\end{array}$ & $\begin{array}{c}45,4 \% \\
(+7,8 \%)\end{array}$ & \multicolumn{3}{|c|}{$\begin{array}{c}34 \% \\
(+2 \%)\end{array}$} & $\begin{array}{l}21,2 \% \\
(+1 \%)\end{array}$ & $\begin{array}{c}32,7 \% \\
(+1,7 \%)\end{array}$ & $\begin{array}{l}49,6 \% \\
(+8 \%)\end{array}$ & $\begin{array}{c}21,7 \% \\
(+6,9 \%)\end{array}$ \\
\hline
\end{tabular}

Source: Research results ${ }^{[1]}$

The requirements of the EU Directives met by all the countries under analysis are those of establishing an independent regulatory body as well as a regulatory framework for electricity transmission and sources in total electricity generation varies between countries. The share of renewable sources in the total generation of electricity is growing but with different intensity for each of the countries. Also, given that every 
electric utility in this research has plans for investing in large-scale renewable power plant projects (mostly wind-based), and the fact that investment in renewable energy sources has received important incentives, further growth of the renewable energy share is to be expected.

The share of the largest electricity producer in total generation of electricity is generally very high and does not significantly differ between countries. The data for Bosnia and Herzegovina relates only to one of the three incumbent electric utilities, while the combined share of three state owned electric utilities in Bosnia and Herzegovina exceeds $98 \%$. Slovenia is the only country facing significant competition in the production process. Electricity exchange is established in all countries except Bosnia and Herzegovina and Macedonia (although there are plans for its establishment). Coupling of individual electricity exchanges of the selected countries into a mutual power exchange is also very likely.

Regarding the restructuring process in the observed electric utilities, in terms of internal restructuring and reorganization as well as functional and legal separation of non-regulated activities (production and supply) almost every observed electric utility (apart from ELEM, EP HZ HB and EP CG) carried out a certain form of restructuring and /or reorganization (they have been restructured into a group, holding or a concern). Electricity transmission is formed as a separate legal entity in all countries, while the Distribution System Operator (DSO) is organized differently in every observed country. As previously stated, Macedonian DSO is privatized and separated from the incumbent power company. Slovenian DSO is organized as a state-owned enterprise separated from the incumbent electric utility. In Serbia and
Montenegro, as well as Croatia the DSO is formally separated from the incumbent electric utility but still operates within the parent company, while distribution system operators in EP HZ HB and EP $\mathrm{BiH}$ and ERS continue to be a part of a state-owned vertically integrated enterprise. ERS actually has five distribution companies but they are not functionally separated from the electricity supply activities.

Even though the majority of DSOs have been in some way separated from the incumbent electric utility, they are still stateowned with the exception of Macedonia. It has not been generally established that stateowned electric utility companies cannot effectively operate in liberalized markets or that private-owned enterprises are always more profitable. (Barbu, Kalashnikov \& Kempert, 2003).

\subsection{The degree of internationalization of electric utilities}

For the purpose of evaluating the degree of internationalization (Table 4), the business segments in which companies operate in foreign markets are noted, as well as the number of countries in which the companies operate. Apart from the Croatian HEP and the Slovenian HSE who have multiple businesses listed outside of their borders, other electric utilities are oriented on their domestic markets, with the exception of Serbian EPS and EPCG from Montenegro who have a single business listed abroad. However, the international businesses are limited to electricity trading, as electricity companies trading outside their borders usually set up subsidiaries abroad, most likely due to tax treatment and legal regulation on electricity trading. Croatian HEP is the only electric utility operating abroad in the segment of electricity production. However, the reason for the internationalization of 
Table 4: Internationalization degree indicators

\begin{tabular}{|c|c|c|c|c|}
\hline State & Electric utility & $\begin{array}{c}\text { International } \\
\text { businesses }\end{array}$ & $\begin{array}{l}\text { Number of } \\
\text { countries }\end{array}$ & Business activities \\
\hline Croatia & HEP Group & Yes & 5 & $\begin{array}{c}\text { Electricity trading } \\
\text { Electricity production }\end{array}$ \\
\hline \multirow{3}{*}{$\begin{array}{l}\text { Bosnia and } \\
\text { Herzegovina }\end{array}$} & $\begin{array}{l}\text { Public company Elektroprivreda } \\
\text { Hrvatske zajednice Herceg Bosne }\end{array}$ & No & 0 & - \\
\hline & $\begin{array}{l}\text { Public company Elektroprivreda Bosne } \\
\text { i Hercegovine }\end{array}$ & Yes & 1 & Tourism \\
\hline & $\begin{array}{l}\text { Mixed holding company } \\
\text { Elektroprivreda Republike Srpske }\end{array}$ & No & 0 & - \\
\hline Serbia & Public company Elektroprivreda Srbije & Yes & 1 & Electricity trading \\
\hline Slovenia & Holding Slovenske Elektrarne & Yes & 6 & Electricity trading \\
\hline Montenegro & Elektroprivreda Crne Gore AD Nikšić & No & 1 & Electricity trading \\
\hline Macedonia & ELEM Macedonian power plants & No & 0 & - \\
\hline
\end{tabular}

Source: Research results

electricity generation in this case is the fact that HEP owns a stake in the Krško (Slovenia) nuclear power plant, as well as the pump-hydroelectric power plant Buško Blato (Bosnia and Herzegovina). This is due to the former socio-political relations, i.e. the investments in these objects were made at the time when Croatia was a part of Yugoslavia. EP BiH owns a hotel on the territory of the Republic of Croatia so it cannot be perceived as an internationally oriented electric utility in the sense of the electricity business. It should also be taken into account that ERS participates in Serbian power exchange (SEEPEX), and EP HZ HB has plans to participate in Croatian power exchange (CROPEX) in 2018.

Based on the data acquired in this research it is evident that most electric utilities in the selected countries do not operate outside of their borders which by itself confirms the research findings by Li, Sun, \& Liu (2006) stating that developing countries do not adopt internationalization (globalization) growth strategies due to the fact that they originate from relatively small econo- mies and thus cannot compete with large electric utilities of the developed countries.

\subsection{Diversification and innovation in electric utilities}

When considering the degree of diversification for the observed companies it is noticeable that the electric utilities attempt to diversify (at least partially) their business activities. Diversification of incumbent electric utility's activities is particularly present in HEP, EP BiH, HSE and ELEM. Every electric utility analyzed also has plans for future investments into renewable energy sources or new production facilities therefore implementing innovations into their current production activities.

It is important to note that for the purpose of this article the existence of diversification growth strategies does not refer to diversification in the characteristics of electricity as a product offered to consumers. Electric utilities active in the electricity supply process may tailor their final product to meet the needs of a specific group of consumers or even adopt the individual 
Table 5: Diversification of electric utilities

\begin{tabular}{|c|c|c|c|}
\hline State & Electric utility & $\begin{array}{c}\text { Activates } \\
\text { outside of core } \\
\text { businesses }\end{array}$ & Description \\
\hline Croatia & HEP Group & 6 & $\begin{array}{l}\text { managing energy efficiency projects } \\
\text { asset management } \\
\text { telecommunications } \\
\text { consulting } \\
\text { teaching and learning center }\end{array}$ \\
\hline \multirow{3}{*}{$\begin{array}{l}\text { Bosnia and } \\
\text { Herzegovina }\end{array}$} & $\begin{array}{l}\text { Public company Elektroprivreda } \\
\text { Hrvatske zajednice Herceg Bosne }\end{array}$ & 0 & - \\
\hline & $\begin{array}{l}\text { Public company Elektroprivreda Bosne i } \\
\text { Hercegovine }\end{array}$ & 6 & $\begin{array}{l}\text { coal mines } \\
\text { production of equipment } \\
\text { tourism } \\
\text { transport mechanism production } \\
\text { metering and energy management }\end{array}$ \\
\hline & $\begin{array}{l}\text { Mixed holding company Elektroprivreda } \\
\text { Republike Srpske }\end{array}$ & 1 & energy research and development center \\
\hline Serbia & Public company Elektroprivreda Srbije & 1 & coal mines \\
\hline Slovenia & Holding Slovenske Elektrarne & 4 & $\begin{array}{l}\text { engineering and facility construction } \\
\text { coal mines }\end{array}$ \\
\hline Montenegro & Elektroprivreda Crne Gore AD Nikšić & 0 & - \\
\hline Macedonia & ELEM Macedonian power plants & 6 & $\begin{array}{l}\text { coal mines } \\
\text { tourism } \\
\text { production of equipment } \\
\text { maintenance and transportation }\end{array}$ \\
\hline
\end{tabular}

Source: Research results

approach to certain consumers (for example by defining groups of customers with specific electricity prices or by offering the so-called "green" energy). For the purpose of this analysis diversification is noted only if the electric utility owns more than $50 \%$ of stake in a separate undertaking and is engaged in a business that does not directly refer to the core business of the company.

\subsection{Identification of growth strategies of the electric utilities}

In order to link the above-mentioned data and define the growth strategies of the electric utilities in the selected countries, i.e. to define the growth strategies of incumbent electric utilities in the context of the current and comprehensive changes brought about by the deregulation of the electricity market, it is necessary to take into account the specifics of each country. Using the proposed typology and taking into account the evaluated degree of deregulation /market liberalization, as well as the degree of internationalization of business based on the collected data, growth strategies adopted by electric utilities in selected countries have been identified. Figure 2 illustrates the results obtained.

Research indicates that most incumbent electric utilities operate in only partially deregulated electricity markets. Despite the formal liberalization of the electricity market, the entry of new competitors and the changes that market liberalization inevitably brings about are taking place at a slower pace than anticipated. Electricity companies 


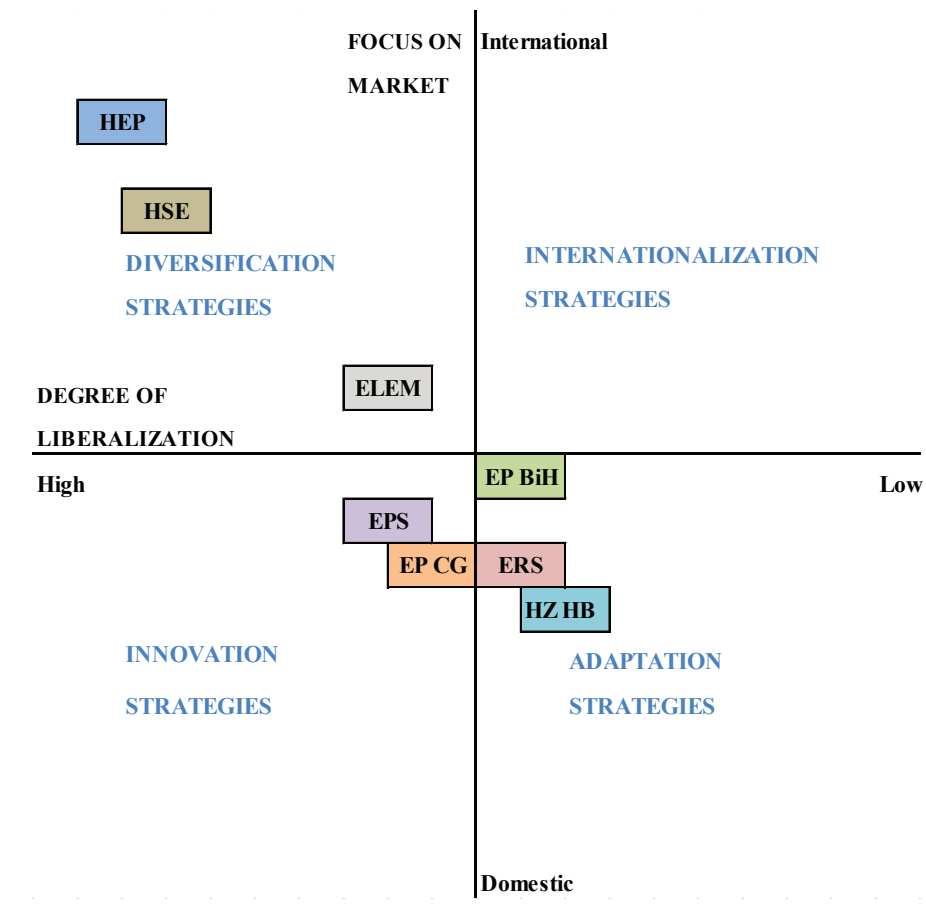

Source: Research results

Figure 2: Growth strategies of selected incumbent electric utilities in context of market liberalization and deregulation

in Slovenia and Croatia, considering the fact that they have liberalized their electricity markets earlier than other countries show a higher degree of deregulation. Even though incumbent electric utilities in Slovenia and Croatia are not competing in the global markets/developed economies, they are exploiting new market opportunities for their growth and development through internationalization of their electricity trade segments as well as diversification of their business activities. The same can be said of the Macedonian ELEM which has significantly differentiated its businesses into other ventures, although on a smaller scale.

Electric utilities in Bosnia and Herzegovina adopted the adaptation growth strategies. These incumbent electric utilities are still trying to adapt to the current market conditions and have no clear and unambiguously defined growth strategies to compete efficiently in a liberalized electricity market. However, since they are also obligated to comply with certain requirements set by the EU Directives, the degree of liberalization is expected to increase in the years to come, placing them in innovation growth strategies group. EP BiH's higher degree of internationalization in comparison to the aforementioned electric power utilities from Bosnia and Herzegovina arises from its reorganization as well as the higher degree of diversification of its activities.

Serbian EPS has separated its DSO and Supply but has not performed any major restructuring and reorganization of its activities. They also have a significant share in other companies in the area of electricity 
generation, and own an electricity trading company in Slovenia, which indicates a higher degree of diversification. EPCG has separated its DSO, and it is partly privatized. These electric utilities adopt the innovation growth strategies and are still adapting to the requirements of the EU Directives, but are finding new investment options - whether into renewable energy sources (EPCG) or by entering into joint ventures with private investors into new production facilities (EPS).

These findings realistically depict the current growth strategies of the electric utilities in the context of electricity market liberalization and provide a basis for further investigation into the dynamics of changes for each selected electric utility.

\section{CONCLUSION}

This paper analyzed the growth strategies of electric utilities taking into account the degree of liberalization/deregulation of the electricity market. The basic idea was to assess whether the lower degree of deregulation is associated with slower and less comprehensive changes in the power sector and the electricity industry. Findings from this research indicate that the degree of liberalization does in fact, affect electric utilities' growth strategies.

Enterprises that have not yet adapted their strategies to the new market conditions are mostly oriented towards maintaining their positions in the domestic markets and have based their growth strategies on innovation. Companies that have adjusted their strategies to the new market conditions to a greater extent are found to be adopting growth strategies based on diversifying their businesses by simultaneously investing in new technologies and setting up subsidiaries beyond their borders. A typology was developed in order to compare different growth strategies of incumbent electric utilities by evaluating their market orientation and the degree of liberalization in their countries. Findings suggest two main factors that have slowed down changes in the electric utilities' growth strategies.

The first factor refers to the fact that, despite the conditions set by Energy Community and the obligation of compliance with the European Union's legislation in the domain of electricity market, incumbent electric power utilities in some countries have not yet formally separated their distribution system operators which significantly disables new suppliers from entering the market. In addition, cross-subsidization between customer groups is still present and higher electricity prices for commercial customers subsidize low electricity prices for households. Even though regulatory agencies in said countries support the reduction of cross-subsidization, electric utility companies are not willing to converge the electricity prices between customer groups. The reasons for this can be found in the fact that the incumbent electric utilities are still state owned enterprises and that by keeping the low prices of electricity governments implement a kind of social/welfare policy. The shortage of official programs for the protection of economically disadvantaged customers results in the groups of customers with average/higher income also being exempt from paying the market price for electricity, thus the electricity prices for all household consumers are kept below their market value. On the other hand, an increase in the price of an indispensable commodity such as electricity is an unpopular political move for the governments, so the cross-subsidization is actually a political decision. Since competitors (new electricity suppliers) are mostly focusing their marketing activities 
on commercial customers, incumbent electric utility companies are put in an unfavorable position. Therefore, by slowing down the liberalization process, the electric utilities are trying to keep their position in the market in order to ensure their profitability without having to raise the electricity prices for households significantly.

The second factor refers to the lack of diversification activities in most electric utilities. The observed countries are relatively small economies but still facing the same rules and regulations related to the restructuring of the power sector and the liberalization of the electricity market as the developed economies in the European Union. These companies can therefore achieve growth either through investments in new production facilities primarily from renewable energy sources or through diversification of their activities or even by combining these two strategies. Companies analyzed in this paper have significant untapped potential in electricity industry given the natural resources and their geopolitical position.

Electricity market liberalization effects have been a subject of interest in many studies, in which the assessment of the degree of liberalization has always been based on qualitative subjective evaluation or was limited only to certain variables/indicators. The results obtained in this research, especially regarding the evaluation of the degree of liberalization and deregulation, are based on the author's own estimates. This paper argues that, since the current process of liberalization follows certain "best practices", a composite and universal indicator of the degree of liberalization can and should be constructed as well as reported by relevant institutions in the field of electricity industry statistics. Such information could potentially be valuable not only for scientific purposes but to potential investors and electric utili- ties seeking to find their growth possibilities internationally. In addition, there is an evident need for future research that should help determine dynamics in adjusting the growth strategy of the selected companies to the growing degree of liberalization of the electricity market. In addition, further studies of this matter should take into account the links between the electric utilities themselves, and current strategic orientation of electric utilities that can be directly linked to their growth strategies.

\section{Notes}

[1] The data in Table 3 is collected from reports and websites of individual electric utilities, Eurostat reports and databases, implementation reports and other Energy Community reports, data available on the web pages and in the reports of individual regulatory bodies in selected countries and other databases and publications. Renewable sources / largest producers share data is collected for the year 2015, since that is the newest data available and since there were no major changes in this area in 2016. Growth rates for the renewable sources / largest producers share data refers to data available for the period from 2012 to 2015 (or prior to that period, depending on the availability of data), where + indicates growth, and decline. The abbreviations in Table 3 and further in the article indicate the following:

Electric utilities: HEP Group - Croatian electric utility; EP HZ HB - Public company Elektroprivreda Hrvatske zajednice Herceg Bosne; EP BiH - Public company Elektroprivreda $\mathrm{BiH}$; MH ERS - Mixed holding company Elektroprivreda Republike Srpske; EPS - Public company Elektroprivreda Srbije; HSE - Holding Slovenian Power Plants; EPCG - Elektroprivreda Crne Gore and ELEM - Macedonian power plants; and Regulatory agencies: HERA - Croatian energy regulatory agency; DERK - State electricity 
regulatory commission in Bosnia and Herzegovina, FERK - Regulatory commission for energy in the Federation of Bosnia And Herzegovina; RERS - Regulatory commission for energy in the Republic of Srpska; AERS

\section{References}

1. ACER - Agency for the cooperation of European regulators. (n.d.). http://www. acer.europa.eu/en/Pages/default.aspx

2. AERS - Energy agency of the Republic of Serbia. (n.d.). https://aers.rs/Index. asp?1=2\&a=16.1

3. AGEN - Agencija za energijo Republike Slovenije. (n.d.). https://agen-rs.si/

4. Andrews, R., Boyne, G., Law, J., \& Walker, R. (2009). Strategy, structure and process in the public sector: A test of Miles and Snow model. Public Administration, 87(4), 732-749.

5. Barbu, D., Kalashnikov, V., \& Kempert, C. (2003). Economic Effects of the Liberalization of the European Electricity Market - Simulation Results of a Game Theoretic Modelling Concept. Economics and Law.

6. Bonardi, J. (2004). Global and political strategies in deregulated industries: The asymetric behaviors of former monopolies. Strategic Management Journal, 25, 101-120.

7. Clifton, J., Díaz-Fuentes, D., \& Revuelta, J. (2010). The political economy of telecoms and electricity internationalization in the single market. Journal of European Public Policy, 17(7), 988-1006.

8. DERK - State electricity regulatory comission. (n.d.). https:/www.derk.ba/ en

9. Directive of the European Parliament and the Council. (13. 7 2009). Directive 2009/72/EC - concerning common rules for the internal market in electricity,
- Energy agency in Serbia; AGEN-RS Energy agency in the Republic of Slovenia; REGAGEN - Energy agency in Montenegro and ERC - Regulatory commission for energy in FYR Macedonia.

4(12), 29-67. Official Journal of the EU.

10. Domanico, F. (2007). Concentration in the European electricity industry: The internal market as solution? Energy Policy, 35, 5064-5076.

11. Družić, I., Štritof, I., \& Gelo, T. (2012). A Comprehensive Approach to Regulation of Natural Monopolies - Setting a Fair Rate of Return. Zagreb International Review of Economics \& Business, 15(1), 49-72.

12. ELEM - Macedonian power plants. (n.d.).http://www.elem.com. $\mathrm{mk} /$ ?lang=en

13. Energy Community - Implementation. (n.d.). https://www.energy-community. org/

14. EPCG - Elektroprivreda Crne Gore. (n.d.). http://www.epcg.com/en

15. ERC - Energy regulatory comission of the Republic of Macedonia. (n.d.). http:// www.erc.org.mk/default_en.aspx

16. Ernst, \& Young. (2006). Final Report: Department of Trade and Industry - Research Project on "The Case of Liberalisation”. London: Ernst \& YOung LLP.

17. European Comission - Energy. (n.d.). https://ec.europa.eu/info/energyclimate-change-environment_en

18. EUROSTAT - Energy statistics. (n.d.). $\mathrm{http}$ ://ec.europa.eu/eurostat/web/energy/ data/database

19. FERK - Regulatory Commission for Energy in the Federation of Bosnia and Herzegovina. (n.d.). http://www.ferk. ba/_en/

20. Ferrari, A., \& Giulietti, M. (2005). 
Competition in electricity markets: international experience and the case of Italy. Utilities Policy, (13), 247-255.

21. Ghobardian, A., James, P., Liu, J., \& Viney, H. (1998). Evaluating the Applicapility of the Miles and Snow Typology in a Regulated Public Utility Environment. British Journal of Management, 9, 571-583.

22. Granić, G., Zeljko, M., Moranjkić, I., Andres Martinez, J., Olano, M., \& Jurić, Ž. (2008.). Studija energetskog sektora u BiH. Esss Bih, Final Report, Modul 6.

23. HEP Group. (n.d.). http://www.hep.hr

24. HERA - Croatian energy regulatory agency. (n.d.). Dohvaćeno iz https:// www.hera.hr/en/html/index.html

25. HSE - Holding Slovenian Power Plants. (n.d.). http://www.hse.si/si/

26. Humphreys, P., \& Padgett, S. (2006). Globalization, the European Union and Domestic Governance in Telecoms and Electricity. Governance: An international journal of policy, administration and institutions, 19(3), 383-406.

27. Jamasb, T. (2002). Reform and Regulation of the Electricity Sectors in Developing Countries. DAE Working Paper 0226 (CMI EP 08). Department of Applied Economics, University of Cambridge.

28. Jamasb, T., \& Pollit, M. ( 2005). Electricity Market Reform in the European Union: Review of Progress toward Liberalization \& Integration. The Energy Journal, Special Issue: European Electricity Liberalisation, 26, 11-41.

29. Li, Y., Sun, Y., \& Liu, Y. (2006). An empirical study of state owned enterprizes' market orientation in transitional China. Asia Pacific Journal of Management, 23, 93-113.

30. Mahon, J., \& Murray, E. (1981). Strategic planning for regulated industries. Strategic Management Journal, 2, 251262.

31. Mejía-Dugand, S., Hjelm, O., \& Baas, L. (2017). Public utility companies in liberalized markets- The impact of management models on local and regional sustainability. Utilities Policy, $1-8$.

32. Müller-Jentsch, D. (2001.). The Development of Electricity Markets in the Euro-Mediterranean Area - Trends and Prospects for Liberalization and Regional Integration. Washington D.C.: WORLD BANK Technical Paper.

33. Nakano, M., \& Managi, S. (2008). Regulatory reforms and productivity: An empirical analysis of the Japanese electricity industry. Energy Policy, 36, 201-209.

34. Newbery, D., Strbac, G., Pudjianto, D., \& Noël, P. (2013). Benefits of an integrated european energy market. Revised Final Report Prepared for European Commission.

35. Olley, G., \& Pakes, A. (1996). The dynamics of productivity in the telecomunications equpment industry. Econometrica , 64(6), 1263-1297.

36. Public company Electroprivreda BiH. (n.d.). https://www.elektroprivreda.ba/ eng/page/general-information

37. Public company Elektroprivreda $H Z H B$. (n.d.). http://www.ephzhb.ba/?lang=en\#

38. Public company Elektroprivreda RS. (n.d.). http://www.ers.ba/

39. Public company Elektroprivreda Srbije EPS. (n.d.). http://www.eps.rs/en

40. Ratinen, M., \& Lund, P. (2014). Growth strategies of incumbent utilities as contextualy embedded: Examples from Denmark, Germany, Finland and Spain. Technology in Society, 38, 81-92.

41. REGAGEN Montenegro energy regulatory agency. (n.d.). http://regagen. 
co.me/site_en/public/index.php/index/ artikli?id $=\overline{63}$

42. RERS - Regulatory Commission for Energy of Republic of Srpska . (n.d.). http://reers.ba/en

43. Ringel, M.(2003). Liberalising European electricity markets: opportunities and risks for a sustainable power sector. Renewable and Sustainable Energy Reviews, 7, 485-499.

44. Russo, M. (1992). Power plays: Regulation, diversification and backward integration in the electric utility industry. Strategic Management Journal, 13, 13-27.

45. Schneider, V., \& Jäger, A. (2003). The Privatization of Infrastructures in The Theory of The state: An Empirical Overview and a Discussion of Competing Theoretical Explanations. In: Wubben, E. (Ed.): On Creating Competition and Strategic Restructuring: Regulatory
Reform in Public Utilities. Cheltenham: Edward Elgar.

46. Seabright, P. (2001). Competition, privatisation and productive efficiency: Evidence from the airline industry. Economic Journal, 111(473), 591-619.

47. Stenzel, T., \& Frenzel, A. (2008). Regulating technological change- the strategic reactions of utility companies toward subsidy policies in the German, Spanish and UK electricity markets. Energy policy, 36(7), 2645-2657.

48. Tominov, I. (2008). Liberalizacija tržišta električne energije - Ispunjava li očekivanja? Energija, 57(3), 256-299.

49. Vietor, R.(1994). Contrived competition: Regulation and deregulation in America. Boston: Harvard University Press.

50. Whittington, R. (1993). What is strategy and why does it matter? Guilford: Routledge. 


\section{STRATEGIJE RASTA PRUŽATELJA USLUGA OPSKRBE ELEKTRIČNOM ENERGIJOM U KONTEKSTU DEREGULACIJE I LIBERALIZACIJE TRŽIŠTA ELEKTRIČNE ENERGIJE}

\begin{abstract}
Sažetak
U ovom se radu identificiraju strategije rasta, koje se koriste u komunalnoj industriji električne energije, u kontekstu promjena, do kojih dolazi zbog deregulacije i liberalizacije tržišta električne energije. Strategije u ovoj industriji su rijetko bile predmetom istraživanja u području strateškog menadžmenta, iako je električna energija nezaobilazni dio svakodnevnog života, kao i gospodarstva u cjelini. Stoga je provedena analiza studija slučaja najvećih (prijašnjih monopolskih) tvrtki iz područja opskrbe električnom energijom u Republici Hrvatskoj, Sloveniji, Bosni i Hercegovini, Srbiji, Crnoj Gori i Makedoniji, pri čemu su utvrđene i razlike u razini liberalizacije tržišta, kao i ključna obilježja analiziranih poduzeća. Rezultati istraživanja su pokazali da
\end{abstract}

razina deregulacije može utjecati na strategije rasta pružatelja usluga u opskrbi električnom energijom. U zemljama s nižom razinom deregulacije, pružatelji usluga se fokusiraju na domaće tržište. S druge strane, viša razina deregulacije omogućava pružateljima usluga rast kroz diverzifikaciju ili inovaciju. Uzevši u obzir da analizirana poduzeća funkcioniraju u okviru relativno malih gospodarstava, ona se ne mogu natjecati s pružateljima usluga u razvijenim zemljama te su, osim u međunarodnoj trgovini električnom energijom, uglavnom fokusirani na vlastita domaća tržišta.

Ključne riječi: strategije rasta, pružatelji opskrbe električnom energijom, liberalizacija tržišta električnom energijom, internacionalizacija 